\title{
Karakteristik Teh Daun Bambu Tali (Gigantochloa apus Kurz.) pada Metode Blansir dan Suhu Pengeringan
}

\author{
The Characteristics of Bambu Tali Leaves Tea (Gigantochloa apus Kurz.) in Blanching \\ Method and Dried Temperature
}

\author{
I Gusti Ayu Krisna Dewi, Luh Putu Wrasiati*, G.P. Ganda Putra \\ PS Teknologi Industri Pertanian, Fakultas Teknologi Pertanian, Universitas Udayana, Kampus Bukit \\ Jimbaran, Badung, Kode pos : 80361; Telp/Fax : (0361) 701801.
}

Diterima 06 Mei 2020/ Disetujui 25 Juni 2020

\begin{abstract}
Bambu Tali leaves are part of bamboo plants that have not been used optimally. Bambu Tali leaves can be used as a refreshing drink. The aims of this study is to determine the effect of blanching and drying temperature on the characteristics of the Bambu Tali leaves and to determine method of blanching and drying temperature which can produce the best characteristics of Bambu Tali tea leaves. This study used a Randomized Block Design with two factors. The first factor's is the blanching method that is without blanching, steam blanching, and water blanching. The second factors that is drying temperature that consisting of $50^{\circ} \mathrm{C}, 60^{\circ} \mathrm{C}$, and $70^{\circ} \mathrm{C}$. Data were analyzed by analysis of variance and continued with Tukey test. The results showed that the blanching treatment and drying temperature significantly affected the water content, ash content, extract content in water, total phenolic, $I_{50}$, and organoleptic test. The steam blanching treatment with a drying temperature of $70^{\circ} \mathrm{C}$ is the best treatment to produce Tali's bamboo tea leaves with a characteristics of water content is $5.17 \%$, ash content is $5.52 \%$, extract content in water is $35.70 \%$, total phenolic is $36.92 \mathrm{mg}$ GAE/g, and antioxidant activity of IC $\mathrm{C}_{50} 2,629.06$ ppm, and color scoring of sensory evaluation is 3.55 (yellowish green to green), taste scoring is 3.55 (slightly astringent to astringent), Scent scoring of 3.45 (slightly leaf scent to leaf scent), and overall reception 4.90 (rather like).
\end{abstract}

Keywords: Gigantochloa apus Kurz., blanching, drying temperature, tea.

\section{ABSTRAK}

Daun bambu tali merupakan bagian tanaman bambu yang belum digunakan secara optimal. Daun bambu tali dapat dimanfaatkan menjadi teh daun bambu tali sebagai minuman penyegar. Penelitian ini bertujuan untuk mengetahui pengaruh perlakuan blansir dan suhu pengeringan terhadap karakteristik teh daun bambu tali serta menentukan metode blansir dan suhu pengeringan yang dapat menghasilkan teh daun bambu tali dengan karakteristik terbaik. Penelitian ini menggunakan rancangan acak kelompok pola faktorial dengan dua faktor. Faktor pertama yaitu metode blansir yaitu tanpa blansir, blansir uap, dan blansir air. Faktor kedua yaitu suhu pengeringan yang terdiri atas $50^{\circ} \mathrm{C}, 60^{\circ} \mathrm{C}$, dan $70^{\circ} \mathrm{C}$. Data dianalisis dengan analisis varian dan dilanjutkan dengan uji Tukey. Hasil penelitian menunjukkan bahwa perlakuan blansir dan suhu pengeringan sangat berpengaruh terhadap kadar air, kadar abu, kadar ekstrak dalam air, total fenolik, $\mathrm{IC}_{50}$, dan uji organoleptik. Blansir uap dengan suhu pengeringan $70^{\circ} \mathrm{C}$ merupakan perlakuan yang menghasilkan teh daun bambu tali terbaik dengan karakteristik kadar air

\footnotetext{
*Korespondensi Penulis:

Email :wrasiati@unud.ac.id
} 

5,17\%, kadar abu 5,52\%, kadar ekstrak dalam air 35,70\%, total fenolik 36,92 mg GAE/g, dan aktivitas antioksidan $\mathrm{IC}_{50} 2.629,06 \mathrm{ppm}$, serta skoring warna 3,55 (hijau kekuningan sampai hijau), skoring rasa 3,55 (agak sepat sampai sepat), skoring aroma 3,45 (agak beraroma daun)dan penerimaan keseluruhan 4,90 (agak suka).

Kata kunci: Gigantochloa apus Kurz., blansir, suhu pengeringan, teh.

\section{PENDAHULUAN}

Bambu merupakan jenis tanaman yang banyak ditemukan di lahan masyarakat khususnya di Pulau Bali. Tanaman bambu banyak digunakan sebagai bahan makanan (rebung) dan komponen bangunan (batang). Bambu tali merupakan jenis bambu yang tumbuh dan hidup liar di pinggiran sungai, batas desa, dan lereng perbukitan dari dataran rendah hingga dataran tinggi $( \pm 1300 \mathrm{~m} \mathrm{dpl})$ (Dransfield dan Widjaja, 1995). Bagian daun berwarna hijau tua dari bambu sering digunakan sebagai pembungkus makanan untuk jajanan tradisional seperti pasung, jaja gambir, bendu dan entil. Daun bambu secara umum memiliki sifat antioksidan karena mengandung senyawa fenolik yang dapat membantu meningkatkan imunitas dan mencegah penyakit degeneratif. Penelitian Setiawan et al. (2018) menyatakan eksrak daun bambu tali (Gigantochloa apus) mengandung senyawa alkaloid, saponin, tanin, fenolik, flavonoid, triterpenoid, steroid, dan glikosida yang dapat dimanfaatkan sebagai senyawa antioksidan yang berperan meredam aktifitas radikal bebas. Penelitian Tongco et al. (2014) memanfaatkan daun bambu jenis Schizostachyum lumampao atau disebut 'buho' di Filipina sebagai teh herbal dengan komposisi total fenolik 13,5 $\mathrm{mg}$ GAE/100 $\mathrm{g}$ dan total flavonoid $17,86 \mathrm{mg}$ QE/100 g.

Proses pengolahan melalui tahapan pemanasan seperti blansir dapat mempengaruhi karakteristik produk. Blansir merupakan proses pemanasan cepat untuk menginaktivasi enzim yang umum dilakukan dengan suhu mencapai $100^{\circ} \mathrm{C}$. Blansir dapat dilakukan dengan air panas, uap panas, dan energi microwave. Secara umum proses blansir bertujuan untuk menginaktivasi enzim polifenol oksidase. Desrosier (1988) menyatakan inaktivasi enzim dilakukan dengan blansir pada air mendidih atau uap air dengan waktu 1-3 menit untuk sayuran daun. Dalam penelitian Pratiwi dan Wiadnyani (2016) perlakuan blansir terbaik bahan daun pegagan adalah suhu $80^{\circ} \mathrm{C}$ selama 60 detik.

Selain itu, proses pengeringan juga dapat mempengaruhi karakteristik produk. Beberapa penelitian mengenai pengaruh suhu pengeringan memiliki pengaruh nyata terhadap karakteristik teh. Penelitian Patin et al. (2018) menyatakan perlakuan suhu pengeringan terbaik teh daun sambiloto adalah suhu $60^{\circ} \mathrm{C}$. Penelitian Rusnayanti (2018) menyatakan suhu pengeringan terbaik teh hijau daun kakao adalah suhu $50^{\circ} \mathrm{C}$ selama 40 menit dan penelitian Astatin (2014) menunjukkan pengeringan terbaik dalam pembuatan teh daun sirsak dan kulit jeruk purut adalah suhu $50^{\circ} \mathrm{C}$ selama 30 menit.

\section{METODE PENELITIAN}

\section{Bahan dan Alat}

Bahan yang digunakan daun bambu tali (daun muda dengan posisi 1-3 dihitung dari pucuk daun dengan panjang 10-20 cm) diperoleh dari Desa Kekeran-Badung serta bahan kimia merek Merck (metanol PA, $\mathrm{Na}_{2} \mathrm{CO}_{3}$ dan reagen Folin-cioccalteu), akuades, asam galat (Sigma-aldrich) dan kristal DPPH (Himedia) serta peralatan yang digunakan termometer, panci, aluminium foil, oven (Blue M), gelas beker (Pyrex), timbangan analitik (Shimadzu), pipet volume, blender (Philips), pipet tetes, desikator, cawan porselen, labu ukur, tanur, penangas air, gelas piala, tabung reaksi (Iwaki), vortex, 
spektrofotometer (Geneyes 10S UV -Vis), dan ayakan (Retsch) 40 mesh.

\section{Pelaksanaan Penelitian Persiapan Bahan}

Daun bambu tali dibersihkan dengan air mengalir dan diangin-anginkan, kemudian dipotong dengan ukuran sekitar $3 \mathrm{~cm}$ x $3 \mathrm{~cm}$ agar diperoleh bahan dengan ukuran yang relatif sama.

\section{Pengolahan Teh Daun Bambu Tali}

Potongan daun bambu tali sebanyak $150 \mathrm{~g}$ (setiap perlakuan) diblansir sesuai perlakuan (tanpa blansir, blansir uap, blansir air) selama 60 detik. Setelah diblansir, bahan diangkat dan diangin-anginkan. Daun bambu kemudian dimasukkan ke dalam oven sesuai dengan perlakuan suhu pengeringan $\left(50 \pm 2^{\circ}\right.$, $60 \pm 2^{\circ} \mathrm{C}, 70 \pm 2^{\circ} \mathrm{C}$ ). Daun bambu yang sudah kering dihancurkan dengan blender, kemudian diayak dengan ayakan ukuran 40 mesh agar diperoleh ukuran yang seragam. Sampel teh daun bambu tali selanjutnya dimasukkan ke dalam plastik flip sebelum dianalisis.

\section{Variabel yang Diamati \\ Kadar Air (Apriyantono et al., 1989)}

Cawan aluminium dikeringkan di dalam oven 60 menit dan didinginkan di dalam desikator, kemudian cawan ditimbang dengan neraca analitik (catat berat cawan kosong). Bahan ditimbang sebanyak 1-3 g pada cawan kemudian dioven pada suhu $105^{\circ} \mathrm{C}$ selama 4 jam. Cawan didinginkan di dalam desikator, kemudian dikeringkan kembali sampai diperoleh bobot konstan. Perhitungan kadar:

Kadar air $(\% b b)=\frac{W-(W 1-W 2}{W} \times 100 \%$

Keterangan :

W: bobot contoh sebelum dikeringkan $(\mathrm{g})$

W1: bobot contoh setelah dikeringkan + cawan kosong $(\mathrm{g})$

W2: bobot cawan kosong (g)

Kadar Abu (Apriyantono et al., 1989)
Cawan porselin dikeringkan di dalam oven 60 menit dan didinginkan di dalam desikator, kemudian cawan ditimbang dengan timbangan analitik (dicatat berat cawan kosong). Sampel ditimbang sebanyak 1-3 g pada cawan, kemudan dibakar atau diarangkan pada pemanas (sampai tidak berasap). Ditanur pada furnance suhu $600^{\circ} \mathrm{C}$ sampai menjadi abu putih ( $\pm 3-4$ jam), tanur dimatikan kemudian ditunggu sampai dingin lalu cawan dipindahkan ke dalam desikator untuk didinginkan 15 menit dan ditimbang (dicatat berat abu+cawan). Penimbangan diulangi hingga diperoleh bobot tetap (W2).

$$
\begin{gathered}
\text { Kadar } a b u(\% \text { bk })=\frac{(W 2-W 1)}{W} \times 100 \% \\
=\frac{\text { Kadar abu }}{(100-\text { Kadar air })} \times 100 \%
\end{gathered}
$$

Keterangan:

W: bobot contoh setelah dikeringkan $(\mathrm{g})$

W1: bobot cawan kosong (g)

W2: bobot contoh + cawan sesudah diabukan (g)

\section{Kadar Ekstrak dalam Air (SNI 3836:2013)}

Kadar ekstrak dalam air dihitung dari bagian yang larut dalam air mendidih, disaring dan diuapkan. Cawan dipanaskan pada oven dengan suhu $(105 \pm 2)^{\circ} \mathrm{C} \pm 1$ jam dan didinginkan pada desikator 30 menit kemudian ditimbang (W0). 2 g sampel dimasukkan ke dalam gelas piala $300 \mathrm{~mL}$, ditambahkan $200 \mathrm{ml}$ air mendidih dan didiamkan 1 jam. Disaring ke dalam labu ukur $500 \mathrm{ml}$ dan dibilas dengan air panas sampai warna larutan jernih, kemudian didinginkan dan ditambah akuades hingga tanda garis. Filtrat dipipet $50 \mathrm{ml}$ ke dalam cawan (sudah diketahui bobotnya) dan dikeringkan di atas penangas air. Dipanaskan dalam oven 2 jam, didinginkan dalam desikator dan ditimbang. Panaskan kembali di dalam oven 1 jam, didinginkan di dalam desikator dan ditimbang (W2). Pekerjaan diulangi hingga perbedaan hasil penimbangan tidak melebihi $1 \mathrm{mg}$. 
Perhitungan kadar ekstrak dalam air:

Kadar Ekstrak dalam air $(\%)=$

$$
\frac{W 2-W 0}{W 1-W 0} \times P \times \frac{100}{100-K A} \times 100
$$

Keterangan:

W0: bobot cawan kosong dan tutupnya (g)

W1: bobot cawan kosong+sampel+tutup (g)

W2: bobot cawan kosong, sampel terekstrak dan tutupnya $(\mathrm{g})$

$\mathrm{P}$ : pengenceran

KA : kadar air

\section{Total Fenolik (Sakanaka et al., 2003)}

Pembuatan Kurva Standar Asam Galat

Kurva standar dibuat dengan menimbang 0,01 $\mathrm{g}$ asam galat, kemudian diencerkan menjadi $100 \mathrm{~mL}$ pada labu takar dengan akuades. Kemudian dibuat seri pengenceran masing-masing sebanyak $5 \mathrm{~mL}$ dengan konsentrasi 0, 10, 20, 40, 60, 80, 100 $\mathrm{mg} / \mathrm{L}$ dengan pelarut metanol $85 \%$. Kemudian dipipet sebanyak $0,4 \mathrm{~mL}$ dari masing-masing seri dan ditempatkan di tabung reaksi. Masing-masing seri ditambahkan reagen Folin-Ciocalteu sebanyak 0,4 $\mathrm{mL}$, kemudian divortex dan diinkubasi selama 6 menit. 4,2 $\mathrm{mL} \mathrm{Na} \mathrm{CO}_{3}$ $5 \%$ ditambahkan ke dalam maisng-masing seri, kemudian divortex dan diinkubasi selama 30 menit pada suhu ruang. Dilakukan pengukuran absorbansi pada panjang gelombang $760 \mathrm{~nm}$ dan dibuat kurva kalibrasi serta persamaan regresi linier dari data yang didapat.

\section{Analisis Kadar Total Fenolik pada Sampel}

Sampel ditimbang sebanyak $\pm 0,01 \mathrm{~g}$ dan dilarutkan dengan metanol $85 \%$ dengan labu ukur $5 \mathrm{~mL}$, kemudian divortex. Sampel yang sudah diencerkan dipipet sebanyak 100 $\mu \mathrm{L}$, ditambahkan $300 \mu \mathrm{L}$ metanol $85 \%$, ditambahkan $400 \mu \mathrm{L}$ reagen Folin-Ciocalteu, divortex hingga homogen dan diinkubasi 6 menit. Ditambahkan $\mathrm{Na}_{2} \mathrm{CO}_{3} 5 \%$ sebanyak 4,2 $\mathrm{mL}$ dan diinkubasi 30 menit pada suhu ruang. Kemudian dilakukan pengukuran absorbansi pada panjang gelombang $760 \mathrm{~nm}$.
Perhitungan total fenolik menggunakan rumus persamaan $\mathrm{y}=\mathrm{ax}+\mathrm{b}$, dimana y menunjukkan absorbansi, $\mathrm{x}$ menunjukkan konsentrasi asam galat, a menunjukkan intersep, dan $b$ adalah konstanta. Total kandungan fenol pada ekstrak menunjukkan sebagai mg ekuivalen asam galat/gram sampel. Perhitungan total fenolik:

$$
\begin{aligned}
& \text { Total fenol }\left(\frac{\mathrm{mg} \mathrm{GAE}}{\mathrm{g}}\right) \\
& =\left(\frac{\mathrm{X}\left(\frac{\mathrm{mg}}{\mathrm{ml}}\right) \times \text { volume larutan }(\mathrm{ml})}{\text { Sampel }(\mathrm{g})} \times \mathrm{FP}\right.
\end{aligned}
$$

$\mathrm{X}=$ Konsentrasi yang diperoleh dari persamaan regresi linier kurva standar asam galat

$\mathrm{FP}=$ Faktor pengencer

\section{Aktivitas Antioksidan (IC50) dengan Metode DPPH (Prayoga, 2013)}

Sampel ditimbang sebanyak $0,1 \mathrm{~g}$ kemudian diencerkan dengan metanol sampai volume $5 \mathrm{~mL}$ dalam labu ukur dan divortex. Kemudian dibuat konsentrasi sampel masingmasing sebanyak $1 \mathrm{~mL}$ dengan konsentrasi 0 , 20, 40, 60, 80, 100 ppm dalam tabung reaksi. Ditambahkan metanol sebanyak $980 \mu \mathrm{L}, 960$ $\mu \mathrm{L}, 940 \mu \mathrm{L}, 920 \mu \mathrm{L}, 900 \mu \mathrm{L}$ secara berurutan pada masing-masing kosentrasi dan DPPH 1 $\mathrm{mL}$. Selanjutnya sampel divortex dan diinkubasi selama 30 menit pada suhu kamar. Absorbansi kurva standar masing-masing sampel kemudian dibaca pada panjang gelombang $517 \mathrm{~nm}$.

Penentuan aktivitas antioksidan:

$$
X=\frac{Y-B}{A} \times 100
$$

$X$ : konsentrasi sampel $(\mu \mathrm{g} / \mathrm{ml})$

$\mathrm{Y}$ : daya hambat sebesar 50 persen

A: koefisien $\mathrm{X}$ yang diperoleh dari persamaan regresi linier

B: konstanta yang diperoleh dari persamaan regresi linier

\section{Uji Organoleptik (Soekarto, 1985)}

Uji organoleptik teh daun bambu tali dilakukan dengan uji skoring warna, rasa, dan 
aroma, serta uji hedonik untuk mengetahui tingkat kesukaan panelis secara keseluruhan. Sampel seduhan teh daun bambu tali dibuat dengan menyiapkan $2 \mathrm{~g}$ bubuk teh daun bambu tali (kantong celup) dimasukkan ke dalam gelas, kemudian dimasukkan air panas $\left(<100^{\circ} \mathrm{C}\right)$ sebanyak $200 \mathrm{~mL}$ dan diseduh selama 2 menit (Horzic et al, 2009). Sampel seduhan teh dihadapkan kepada panelis untuk dilakukan uji organoleptik. Uji skoring menggunakan panelis semi terlatih sebanyak 20 orang. Pada uji skoring dilakukan tahap seleksi pendahuluan berupa Uji Duo-Trio untuk mengukur kemampuan panelis dalam mendeteksi sifat sensori, para panelis diminta untuk menyatakan perbedaan antara tiga contoh yang disajikan. Panelis yang lulus uji Duo-Trio dapat melanjutkan tahap selanjutnya sebagai panelis uji skoring yang terdiri atas skoring warna (nilai $1=$ bening, $2=$ kekuningan, 3=hijau kekuningan, 4=hijau,
$5=$ sangat hijau); skoring rasa (nilai 1=sangat tidak sepat, $2=$ tidak sepat, $3=$ agak sepat, 4=sepat, 5=sangat sepat); skoring aroma (nilai 1=sangat tidak beraroma, 2=tidak beraroma, 3=agak beraroma, 4=beraroma, $5=$ sangat beraroma) dan uji hedonik (nilai $1=$ sangat tidak suka, $2=$ tidak suka, $3=$ sedikit tidak suka, 4=netral, 5=agak suka, 6=suka, $7=$ sangat suka.

\section{HASIL DAN PEMBAHASAN}

\section{Kadar Air}

Hasil analisis ragam menunjukkan bahwa blansir dan suhu pengeringan serta interaksinya berpengaruh sangat nyata $(\mathrm{P} \leq 0,01)$ terhadap kadar air teh daun bambu tali. Nilai rata-rata kadar air teh daun bambu tali dapat dilihat pada Tabel 1.

Tabel 1. Nilai rata-rata kadar air $(\%$ bb) teh daun bambu tali pada perlakuan blansir dan suhu pengeringan

\begin{tabular}{lccc}
\hline \multicolumn{1}{c}{ Blansir $\left({ }^{\circ} \mathrm{C}\right)$} & $50^{\circ} \mathrm{C}$ & $60^{\circ} \mathrm{C}$ & $70^{\circ} \mathrm{C}$ \\
\cline { 2 - 4 } & $6,58 \pm 0,22^{\mathrm{a}}$ & $6,44 \pm 0,22^{\mathrm{a}}$ & $6,12 \pm 0,22^{\mathrm{b}}$ \\
Tanpa blansir & $5,69 \pm 0,18^{\mathrm{d}}$ & $5,41 \pm 0,26^{\mathrm{e}}$ & $5,17 \pm 0,22^{\mathrm{f}}$ \\
Blansir uap $\left(83 \pm 2^{\circ} \mathrm{C}\right)$ & $6,02 \pm 0,30^{\mathrm{b}}$ & $5,95 \pm 0,17^{\mathrm{bc}}$ & $5,84 \pm 0,28^{\mathrm{cd}}$ \\
Blansir air $\left(83 \pm 2{ }^{\circ} \mathrm{C}\right)$ &
\end{tabular}

Keterangan: huruf berbeda di belakang nilai rata-rata menunjukkan perbedaan yang nyata pada taraf kesalahan $5 \%$ $(\mathrm{P} \leq 0,05)$. Data merupakan rata-rata dari dua kelompok pada masing-masing perlakuan

Tabel 1 menunjukkan terjadi penurunan kadar air pada setiap perlakuan blansir seiring peningkatan suhu pengeringan. Kadar air tertinggi diperoleh perlakuan tanpa blansir dengan suhu pengeringan $50^{\circ} \mathrm{C}$ yaitu $6,58 \pm 0,22 \%$ sama dengan perlakuan tanpa blansir suhu pengeringan $60^{\circ} \mathrm{C}$ yaitu $6,44 \pm 0,22 \%$ sedangkan kadar air terendah diperoleh perlakuan blansir uap dengan suhu pengeringan $70^{\circ} \mathrm{C}$ yaitu $5,17 \pm 0,22 \%$.

Penurunan kadar air pada perlakuan blansir terjadi karena pembengkakan granula pati yang membuat sifat permeabel dinding sel semakin meningkat, sehingga air yang dapat diserap oleh bahan pada saat blansir lebih banyak. Selain itu, rongga bahan menjadi lebih luas dan dapat menyerap serta menguapkan air pada saat proses pengeringan bahan. Peningkatan suhu pengeringan juga membantu menurunkan kadar air, semakin tinggi suhu pengeringan semakin besar uap panas yang dialirkan pada bahan sehingga air yang diuapkan juga semakin besar (Yuliani, 2013).

Penelitian Asgar et al. (2006) blansir uap pada kubis menghasilkan kadar air lebih rendah $7,36 \%\left(85^{\circ} \mathrm{C}, 5\right.$ menit), daripada blansir air $8,58 \%\left(85^{\circ} \mathrm{C}, 5\right.$ menit). Perlakuan blansir air memiliki kadar air lebih tinggi, 
karena bahan berikatan langsung dengan molekul air dan molekul zat gizi lainnya. Kadar air yang didapatkan pada penelitian ini ialah $5,17 \%$ - $6,56 \%$ sehingga memenuhi persyaratan SNI 3836:2013 tentang teh kering dalam kemasan yang memiliki standar kadar air sebesar maksimal 8\%. Blansir uap dengan suhu pengeringan $70^{\circ} \mathrm{C}$ merupakan perlakuan dengan karakteristik terbaik dengan kadar air terendah, sehingga dapat memaksimalkan masa simpan produk.

\section{Kadar Abu}

Hasil analisis ragam menunjukkan bahwa blansir dan suhu pengeringan serta interaksinya berpengaruh sangat nyata $(\mathrm{P} \leq 0,01)$ terhadap kadar abu teh daun bambu tali. Nilai rata-rata kadar abu teh daun bambu tali dapat dilihat pada Tabel 2 .

Tabel 2 menunjukkan peningkatan kadar abu setiap perlakuan blansir seiring peningkatan suhu pengeringan. Kadar abu tertinggi diperoleh perlakuan blansir uap dengan suhu pengeringan $70^{\circ} \mathrm{C}$ yaitu $5,52 \pm 0,22 \%$, sedangkan kadar abu terendah diperoleh perlakuan tanpa blansir dengan suhu pengeringan $50^{\circ} \mathrm{C}$ yaitu $3,38 \pm 0,23 \%$. Salah satu faktor penyebab tingginya kadar abu adalah proses blansir yang menyebabkan protein terhidrolisis dan menghasilkan logam, karbohidrat, fosfat, dan lipid sehingga lebih banyak mineral terbentuk (Lidiasari et $a l ., 2006)$. Selain itu, proses pengeringan juga mengakibatkan penguarain komponenkomponen ikatan molekul air $\left(\mathrm{H}_{2} \mathrm{O}\right)$ dan juga memberikan peningkatan terhadap kandungan mineral, sehingga terjadi peningkatan kadar abu pada bahan (Hadipernata et al., 2006).

Tabel 2. Nilai rata-rata kadar abu (\% bk) teh daun bambu tali pada perlakuan blansir dan suhu pengeringan

\begin{tabular}{lccc}
\hline \multirow{2}{*}{ Blansir $\left({ }^{\circ} \mathrm{C}\right)$} & \multicolumn{3}{c}{ Suhu Pengeringan } \\
\cline { 2 - 4 } & $3,38 \pm 0,23^{\mathrm{g}}$ & $\left(60^{\circ} \mathrm{C}\right)$ & $\left(70^{\circ} \mathrm{C}\right)$ \\
\hline Tanpa blansir & $5,32 \pm 0,18^{\mathrm{b}}$ & $3,58 \pm 0,20^{\mathrm{f}}$ & $3,71 \pm 0,25^{\mathrm{e}}$ \\
Blansir uap $\left(83 \pm 2^{\circ} \mathrm{C}\right)$ & $4,60 \pm 0,24^{\mathrm{d}}$ & $5,39 \pm 0,21^{\mathrm{b}}$ & $5,52 \pm 0,22^{\mathrm{a}}$ \\
Blansir air $\left(83 \pm 2^{\circ} \mathrm{C}\right)$ & $4,64 \pm 0,21^{\mathrm{cd}}$ & $4,70 \pm 0,28^{\mathrm{c}}$ \\
\hline
\end{tabular}

Keterangan:huruf berbeda di belakang nilai rata-rata menunjukkan perbedaan yang nyata pada taraf kesalahan $5 \%$ $(\mathrm{P} \leq 0,05)$. Data merupakan rata-rata dari dua kelompok pada masing-masing perlakuan

Sudarmadji et al. (1997) menyatakan bahwa semakin tinggi suhu pengeringan, maka kadar abu bahan semakin meningkat. Perpindahan panas yang tinggi menyebabkan komponen abu pada bahan lebih banyak mengalami penguraian (Desrosier, 1988). Penelitian Patin et al. (2018) menghasilkan kadar abu tertinggi pada perlakuan suhu pengeringan $70^{\circ} \mathrm{C}$ yaitu $10,85 \%$. Dwivedi et al. (2006) menyatakan bahwa kandungan pada abu daun bambu terdiri atas $75,90 \%$ $\mathrm{SiO}_{2}, 4,13 \% \quad \mathrm{Al}_{2} \mathrm{O}_{3}, 1,22 \% \quad \mathrm{Fe}_{2} \mathrm{O}_{3}, 7,47 \%$ $\mathrm{CaO}, 1,85 \% \mathrm{MgO}, 0,21 \% \mathrm{Na}_{2} \mathrm{O}, 5,2 \% \mathrm{~K}_{2} \mathrm{O}$, dan $4,02 \%$ lain-lain. Kadar abu yang didapatkan pada penelitian antara 3,38\% $5,52 \%$, sehingga telah memenuhi persyaratan SNI 3836:2013 tentang teh kering dalam kemasan yang memiliki standar kadar abu sebesar maksimal $8 \%$. Blansir uap dengan suhu pengeringan $70^{\circ} \mathrm{C}$ merupakan perlakuan dengan karakteristik terbaik dengan kadar abu yaitu 5,52\%.

\section{Kadar Ekstrak Dalam Air}

Hasil analisis ragam menunjukkan bahwa blansir dan suhu pengeringan sangat berpengaruh $(\mathrm{P} \leq 0,01) \quad$ serta interaksinya berpengaruh nyata $(P \leq 0,05)$ terhadap kadar ekstrak dalam air pada teh daun bambu tali. Nilai rata-rata kadar ekstrak dalam air teh daun bambu tali dapat dilihat pada Tabel 3 .

Tabel 3 menunjukkan peningkatan kadar ekstrak dalam air pada setiap perlakuan blansir seiring dengan peningkatan suhu pengeringan. Kadar ekstrak dalam air 
tertinggi diperoleh perlakuan blansir uap dengan suhu pengeringan $70^{\circ} \mathrm{C}$ yaitu $35,70 \pm 0,33 \%$, sedangkan kadar ekstrak dalam air terendah diperoleh perlakuan tanpa blansir dengan suhu pengeringan $50^{\circ} \mathrm{C}$ yaitu $29,34 \pm 0,45 \%$. Menguapnya molekul air pada bahan menyebabkan semakin meningkatnya senyawa-senyawa yang terlarut ketika dilarutkan kembali dengan pelarut air. Winarno (2008), menyatakan blansir menyebabkan semakin banyaknya air yang diuapkan, sehingga kadar ekstrak yang terukur semakin besar. Kadar ekstrak dalam air merupakan istilah yang digunakan untuk menggambarkan partikel-partikel pada teh herbal yang larut di dalam air seduhan. Kadar ekstrak dalam air yang tinggi menggambarkan kelarutan partikel yang semakin tinggi pula (Gaman dan Sherrington, 1992).

Tabel 3. Nilai rata-rata kadar ekstrak dalam air (\%) teh daun bambu tali pada perlakuan blansir dan suhu pengeringan

\begin{tabular}{lccc}
\hline \multicolumn{1}{c}{ Blansir $\left({ }^{\circ} \mathrm{C}\right)$} & \multicolumn{3}{c}{ Suhu Pengeringan } \\
\cline { 2 - 4 } & $\left(50^{\circ} \mathrm{C}\right)$ & $\left(60^{\circ} \mathrm{C}\right)$ & $\left(70^{\circ} \mathrm{C}\right)$ \\
\hline Tanpa blansir & $29,34 \pm 0,45^{\mathrm{h}}$ & $29,84 \pm 0,39^{\mathrm{g}}$ & $29,95 \pm 0,42^{\mathrm{g}}$ \\
Blansir uap $\left(83 \pm 2^{\circ} \mathrm{C}\right)$ & $34,53 \pm 0,40^{\mathrm{c}}$ & $35,27 \pm 0,35^{\mathrm{b}}$ & $35,70 \pm 0,33^{\mathrm{a}}$ \\
Blansir air $\left(83 \pm 2^{\circ} \mathrm{C}\right)$ & $30,96 \pm 0,66^{\mathrm{f}}$ & $31,45 \pm 0,55^{\mathrm{e}}$ & $32,06 \pm 0,48^{\mathrm{d}}$ \\
\hline
\end{tabular}

Keterangan: huruf berbeda di belakang nilai rata-rata menunjukkan perbedaan yang nyata pada taraf kesalahan $5 \%$ $(\mathrm{P} \leq 0,05)$. Data merupakan rata-rata dari dua kelompok pada masing-masing perlakuan

Penelitian Kusuma et al. (2019) menyatakan kadar air terendah bubuk teh herbal kulit kakao sebesar 6,52\% menghasilkan kadar esktrak dalam air $22,21 \%$ yang lebih besar daripada bubuk dengan kadar air sebesar 11,07\%. Kadar ekstrak dalam air yang diperoleh pada perlakuan blansir air dengan suhu pengeringan $70^{\circ} \mathrm{C}$ serta perlakuan blansir uap dengan suhu pengeringan $50^{\circ} \mathrm{C}, 60^{\circ} \mathrm{C}$, dan $70^{\circ} \mathrm{C}$ sesuai dengan standar SNI 3836:2013 tentang teh kering dalam kemasan dengan standar kadar ekstrak dalam air sebesar minimal 32\%. Proses blansir uap dengan

Tabel 4. Nilai rata-rata total fenolik (mg GAE/g) teh daun bambu tali pada perlakuan blansir dan suhu pengeringan

\begin{tabular}{lccc}
\hline \multirow{2}{*}{ Blansir $\left({ }^{\circ} \mathrm{C}\right)$} & \multicolumn{3}{c}{ Suhu Pengeringan } \\
\cline { 2 - 4 } & $\left(50^{\circ} \mathrm{C}\right)$ & $\left(60^{\circ} \mathrm{C}\right)$ & $\left(70^{\circ} \mathrm{C}\right)$ \\
\hline Tanpa blansir & $24,63 \pm 0,45^{\mathrm{i}}$ & $25,41 \pm 0,39^{\mathrm{h}}$ & $26,80 \pm 0,42^{\mathrm{g}}$ \\
Blansir uap $\left(83 \pm 2^{\circ} \mathrm{C}\right)$ & $31,70 \pm 0,66^{\mathrm{f}}$ & $35,01 \pm 0,40^{\mathrm{c}}$ & $36,92 \pm 0,33^{\mathrm{a}}$ \\
Blansir air $\left(83 \pm 2^{\circ} \mathrm{C}\right)$ & $32,23 \pm 0,55^{\mathrm{e}}$ & $34,45 \pm 0,47^{\mathrm{d}}$ & $35,24 \pm 0,35^{\mathrm{b}}$ \\
\hline
\end{tabular}

Keterangan: huruf berbeda di belakang nilai rata-rata menunjukkan perbedaan yang nyata pada taraf kesalahan $5 \%$ $(\mathrm{P} \leq 0,05)$. Data merupakan rata-rata dari dua kelompok pada masing-masing perlakuan
Tabel 4 menunjukkan peningkatan total fenolik pada setiap perlakuan blansir seiring peningkatan suhu pengeringan. Total fenolik tertinggi diperoleh perlakuan blansir suhu pengeringan $70^{\circ} \mathrm{C}$ merupakan perlakuan dengan karakteristik terbaik dengan kadar ekstrak dalam air paling tinggi yaitu 35,70\%, nilai tersebut sudah sesuai dengan syarat SNI yaitu diatas $32 \%$.

\section{Total Fenolik}

Hasil analisis ragam menunjukkan bahwa blansir dan suhu pengeringan serta interaksinya berpengaruh sangat nyata $(\mathrm{P} \leq 0,01)$ terhadap total fenolik teh daun bambu tali. Nilai rata-rata total fenolik teh daun bambu tali dapat dilihat pada Tabel 4. uap dengan suhu pengeringan $70^{\circ} \mathrm{C}$ yaitu $36,92 \pm 0,33 \mathrm{mg} \mathrm{GAE} / \mathrm{g}$, sedangkan total fenolik terendah diperoleh perlakuan tanpa blansir dengan suhu pengeringan $50^{\circ} \mathrm{C}$ yaitu 
24,63 $\pm 0,45 \mathrm{mg}$ GAE/g. Hasil ini menunjukkan bahwa setiap perlakuan blansir dengan suhu pengeringan yang lebih tinggi dapat meningkatkan nilai total fenolik. Hal ini terjadi karena perlakuan panas yang dilanjutkan dengan suhu yang lebih tinggi membantu proses terbukanya komponen penyusun dinding sel daun, sehingga senyawa polifenol dapat keluar dari sel.

Lund (1975) menyatakan bahwa proses blansir teh hijau dilakukan untuk menginaktifasi enzim polifenol oksidase dapat mencegah terjadinya reaksi pencoklatan. Blansir menyebabkan senyawa polifenol yang berada di dalam vakuola jaringan sel terbuka sehingga senyawa polifenol keluar dari sel, namun perlakuan blansir air yang berhubungan langsung dengan air mendidih menyebabkan dinding sel dan membran plasma cepat mengalami kerusakan, sehingga dapat melarutkan senyawa fenol. Pengeringan juga mempengaruhi peningkatan total fenol, semakin meningkatnya suhu pengeringan menyebabkan total fenol teh daun bambu tali semakin tinggi. Hal ini terjadi karena panas dapat menyebabkan terjadinya kerusakan terhadap komponen penyusun dinding sel daun yaitu karbohidrat (termasuk serat selulosa) dan protein sebagai komponen tidak terlarut. Kerusakan ini dapat memudahkan keluarnya senyawa polifenol dari dalam daun, karena polifenol merupakan senyawa yang memiliki berat molekul rendah sehingga mudah terinfusi ke dalam pelarut (Chu dan Juneja, 1997).

Bahan brokoli segar Penelitian Roy et al. (2009) juga mengalami peningkatan kadar fenol pada brokoli segar dari 135,66 mg GAE/100 g menjadi 144,33 mg GAE/100 g setelah mengalami blansir selama 5 menit. Proses blansir uap dengan suhu pengeringan $70^{\circ} \mathrm{C}$ merupakan perlakuan dengan karakteristik terbaik dengan total fenolik paling tinggi yaitu 36,92 mg GAE/g.

\section{Aktivitas Antioksidan IC50}

Hasil analisis ragam menunjukkan bahwa blansir dan suhu pengeringan serta interaksinya berpengaruh sangat nyata $(\mathrm{P} \leq 0,01)$ terhadap aktivitas antioksidan bubuk teh daun bambu tali. Nilai rata-rata aktivitas antioksidan $\mathrm{IC}_{50}$ dapat dilihat pada Tabel 5.

Tabel 5. Nilai rata-rata aktivitas antioksidan $\mathrm{IC}_{50}(\mathrm{ppm})$ bubuk teh daun bambu tali pada perlakuan blansir dan suhu pengeringan

\begin{tabular}{lccc}
\hline \multirow{2}{*}{ Blansir $\left({ }^{\circ} \mathrm{C}\right)$} & \multicolumn{3}{c}{ Suhu Pengeringan } \\
\cline { 2 - 4 } & $\left(50^{\circ} \mathrm{C}\right)$ & $\left(60^{\circ} \mathrm{C}\right)$ & $\left(70{ }^{\circ} \mathrm{C}\right)$ \\
\hline Tanpa blansir & $4.390,42 \pm 6,76^{\mathrm{a}}$ & $4.056,77 \pm 17,2^{\mathrm{b}}$ & $4.028,68 \pm 16,8^{\mathrm{b}}$ \\
Blansir uap $\left(83 \pm 2^{\circ} \mathrm{C}\right)$ & $3.429,16 \pm 83,6^{\mathrm{d}}$ & $3.329,89 \pm 16,4^{\mathrm{d}}$ & $2.629,06 \pm 86,5^{\mathrm{f}}$ \\
Blansir air $\left(83 \pm 2^{\circ} \mathrm{C}\right)$ & $3.673,03 \pm 39,5^{\mathrm{c}}$ & $3.415,03 \pm 80,5^{\mathrm{d}}$ & $2.961,64 \pm 26,8^{\mathrm{e}}$ \\
\hline
\end{tabular}

Keterangan: huruf berbeda di belakang nilai rata-rata menunjukkan perbedaan yang nyata pada taraf kesalahan $5 \%$ $(\mathrm{P} \leq 0,05)$. Data merupakan rata-rata dari dua kelompok pada masing-masing perlakuan

Tabel 5 menunjukkan bahwa aktivitas antioksidan $\mathrm{IC}_{50}$ terendah diperoleh perlakuan blansir uap dengan suhu pengeringan $70^{\circ} \mathrm{C}$ yaitu $2.629,06 \pm 86,5 \mathrm{ppm}$, sedangkan aktivitas antioksidan tertinggi diperoleh perlakuan tanpa blansir dengan suhu pengeringan $50^{\circ} \mathrm{C}$ yaitu $4.390,42 \pm 6,76$ ppm. Nilai $\mathrm{IC}_{50}$ berbanding terbalik dengan kemampuan aktivitas antioksidan suatu senyawa. Senyawa yang memiliki aktivitas antioksidan semakin tinggi, memiliki nilai $\mathrm{IC}_{50}$ semakin kecil. Aktivitas antioksidan teh daun bambu tali juga dipengaruhi total fenol.

Nilai aktivitas antioksidan $\mathrm{IC}_{50}$ menurun seiring dengan meningkatnya kadar total fenol yang merupakan senyawa bioaktif yang berperan sebagai antioksidan. Menurut Molyneux (2004) IC 50 merupakan 
konsentrasi suatu zat antioksidan yang dapat menghambat radikal bebas sebanyak $50 \%$. Nilai IC $_{50}$ sebesar $>200$ ppm memiliki sifat antioksidan

yang sangat lemah. Bubuk teh daun bambu tali memiliki nilai $\mathrm{IC}_{50}>200 \mathrm{ppm}$, hal ini menjelaskan bahwa kemampuan menangkap radikal bebas bubuk daun bambu tali termasuk dalam kategori sangat lemah. Hal ini juga diperoleh pada penelitian Yuliani dan Dienina (2015) dengan bahan infus daun kelor menghasilkan nilai $\mathrm{IC}_{50}$ sebesar 2.151,33 ppm yang termasuk dalam kategori antioksidan sangat lemah, hal ini diduga karena sampel uji berupa infus daun kelor masih dalam keadaan tidak murni, sehingga zat tersebut kurang aktif namun masih berpotensi sebagai zat antioksidan. Proses blansir uap dengan suhu pengeringan $70^{\circ} \mathrm{C}$ merupakan perlakuan yang menghasilkan karakteristik terbaik dengan aktivitas antioksidan $\mathrm{IC}_{50}$ paling rendah yaitu

\section{$2.629,06 \pm 86,5 \mathrm{ppm}$.}

\section{Uji Organoleptik \\ Uji Skoring Warna}

Hasil analisis ragam menunjukkan bahwa perlakuan blansir dan suhu pengeringan berpengaruh sangat nyata $(\mathrm{P} \leq 0,01)$ terhadap warna seduhan teh daun bambu tali. Nilai rata-rata skoring panelis terhadap warna air seduhan teh daun bambu tali dapat dilihat pada Tabel 6 .

Perlakuan blansir uap dengan suhu pengeringan $70^{\circ} \mathrm{C}$ merupakan produk terpilih dengan skoring warna 3,55 yaitu warna hijau kekuningan sampai hijau. Setiap perlakuan blansir dengan suhu pengeringan lebih tinggi menghasilkan seduhan teh dengan warna hijau kekuningan. Dalam proses inaktivasi enzim pengolahan teh hijau, terjadi pemanasan senyawa klorofil yang menyebabkan perubahan menjadi hijau zaitun karena klorofil diubah menjadi fiofitin.

Tabel 6. Nilai rata-rata uji organoleptik skoring warna, rasa, aroma dan uji hedonik seduhan teh daun bambu tali pada perlakuan blansir dan suhu pengeringan

\begin{tabular}{cccccc}
\hline \multicolumn{2}{c}{ Perlakuan } & \multicolumn{4}{c}{ Uji Organoleptik } \\
\hline Blansir & Suhu pengeringan & Warna & Rasa & Aroma & Hedonik \\
\hline \multirow{3}{*}{ Tanpa blansir } & $50^{\circ} \mathrm{C}$ & $2,65 \pm 0,875^{\mathrm{c}}$ & $3,20 \pm 0,410^{\mathrm{ab}}$ & $2,10 \pm 0,553^{\mathrm{d}}$ & $2,85 \pm 1,137^{\mathrm{c}}$ \\
& $60^{\circ} \mathrm{C}$ & $2,70 \pm 0,733^{\mathrm{bc}}$ & $3,35 \pm 0.489^{\mathrm{ab}}$ & $2,40 \pm 0,503^{\mathrm{cd}}$ & $4,10 \pm 1,021^{\mathrm{ab}}$ \\
& $70^{\circ} \mathrm{C}$ & $2,60 \pm 0,995^{\mathrm{c}}$ & $3,35 \pm 0,489^{\mathrm{ab}}$ & $2,75 \pm 0,550^{\mathrm{bc}}$ & $3,90 \pm 1,021^{\mathrm{abc}}$ \\
Blansir uap & $50^{\circ} \mathrm{C}$ & $2,70 \pm 0,571^{\mathrm{bc}}$ & $3,35 \pm 0,587^{\mathrm{ab}}$ & $3,20 \pm 0,523^{\mathrm{ab}}$ & $3,60 \pm 1,095^{\mathrm{bc}}$ \\
& $60^{\circ} \mathrm{C}$ & $3,50 \pm 0,761^{\mathrm{a}}$ & $3,10 \pm 0,447^{\mathrm{b}}$ & $3,05 \pm 0,510^{\mathrm{ab}}$ & $4,45 \pm 0,945^{\mathrm{ab}}$ \\
& $70^{\circ} \mathrm{C}$ & $3,55 \pm 0,686^{\mathrm{a}}$ & $3,55 \pm 0,605^{\mathrm{ab}}$ & $3,45 \pm 0,605^{\mathrm{a}}$ & $4,90 \pm 0,912^{\mathrm{a}}$ \\
Blansir air & $50^{\circ} \mathrm{C}$ & $3,00 \pm 0,725^{\mathrm{abc}}$ & $3,30 \pm 0,571^{\mathrm{ab}}$ & $3,30 \pm 0,470^{\mathrm{ab}}$ & $4,45 \pm 1,234^{\mathrm{ab}}$ \\
& $60^{\circ} \mathrm{C}$ & $3,20 \pm 0,696^{\mathrm{abc}}$ & $3,65 \pm 0,671^{\mathrm{a}}$ & $3,50 \pm 0,513^{\mathrm{a}}$ & $4,45 \pm 1,191^{\mathrm{ab}}$ \\
& $70^{\circ} \mathrm{C}$ & $3,40 \pm 0,503^{\mathrm{ab}}$ & $3,65 \pm 0,671^{\mathrm{a}}$ & $3,30 \pm 0,733^{\mathrm{ab}}$ & $4,85 \pm 0,933^{\mathrm{a}}$ \\
\hline
\end{tabular}

Keterangan:huruf berbeda di belakang nilai rata-rata menunjukkan perbedaan yang nyata pada taraf kesalahan $5 \%$ $(\mathrm{P} \leq 0,05)$. Data merupakan rata-rata dari dua kelompok pada masing-masing perlakuan

\section{Uji Skoring Rasa}

Hasil analisis ragam menunjukkan bahwa perlakuan blansir dan suhu pengeringan berpengaruh nyata $(\mathrm{P} \leq 0,05)$ terhadap rasa seduhan teh daun bambu tali. Nilai rata-rata skoring panelis terhadap rasa seduhan teh daun bambu tali dapat dilihat pada Tabel 6.

Perlakuan blansir uap dengan suhu pengeringan $70^{\circ} \mathrm{C}$ merupakan produk terpilih dengan skoring rasa 3,55 (rasa agak sepat sampai sepat). Menurut Ramlah (2017) senyawa fenol dapat memberikan rasa pahit dan sepat pada seduhan teh. Secara umum para panelis berkomentar bahwa perlakuan blansir dengan suhu pengeringan yang lebih tinggi menghasilkan rasa (after taste) seduhan teh lebih sepat. 


\section{Uji Skoring Aroma}

Hasil analisis ragam menunjukkan bahwa perlakuan blansir dan suhu pengeringan berpengaruh sangat nyata $(\mathrm{P} \leq 0,01)$ terhadap aroma seduhan teh daun bambu tali. Nilai rata-rata skoring panelis terhadap aroma seduhan teh daun bambu tali dapat dilihat pada Tabel 6 .

Perlakuan blansir uap suhu pengeringan $70^{\circ} \mathrm{C}$ merupakan produk terbaik dengan skoring aroma 3,45 (agak beraroma sampai beraroma). Perlakuan blansir dengan suhu pengeringan yang lebih tinggi menghasilkan aroma daun bambu tali menjadi sangat khas. Menurut Ciptadi dan Nasution (1979) senyawa pembentuk aroma teh terutama terdiri dari minyak atsiri yang bersifat mudah menguap dan bersifat mudah direduksi, sehingga dapat menghasilkan aroma harum pada teh.

\section{Uji Hedonik}

Hasil analisis ragam menunjukkan bahwa perlakuan blansir dan suhu pengeringan berpengaruh sangat nyata $(\mathrm{P} \leq 0,01)$ terhadap uji hedonik teh daun bambu tali. Nilai rata-rata hedonik panelis terhadap teh daun bambu tali dapat dilihat pada Tabel 6.

Perlakuan blansir uap dan blansir air dengan suhu pengeringan $70^{\circ} \mathrm{C}$ merupakan produk dengan nilai penerimaan terbaik. Hal ini menunjukkan bahwa panelis masih dapat menerima produk teh daun bambu tali berdasarkan dari segi warna, rasa dan aroma.

\section{KESIMPULAN}

\section{Kesimpulan}

Berdasarkan penelitian yang telah dilakukan dapat disimpulkan beberapa hal, diantaranya;

1. Interaksi antara metode blansir dan suhu pengeringan sangat berpengaruh terhadap kadar air, kadar abu, kadar ekstrak dalam air, total fenolik, aktivitas antioksidan $\mathrm{IC}_{50}$ serta uji organoleptik (uji skoring; warna, rasa, aroma dan uji hedonik) dan berpengaruh terhadap kadar ekstrak dalam air teh daun bambu tali.

2. Blansir uap suhu pengeringan $70^{\circ} \mathrm{C}$ merupakan perlakuan yang menghasilkan produk teh daun bambu tali terbaik secara analisis kimia dengan karakteristik kadar air 5,17\%, kadar abu 5,52\%, kadar ekstrak dalam air $35,70 \%$, total fenolik 36,92 mg GAE/g, aktivitas antioksidan $\mathrm{IC}_{50}$ 2.629,06 ppm. Produk terpilih dari penilaian sensori adalah dengan skoring warna 3,55 (hijau kekuningan sampai hijau), skoring rasa 3,55 (agak sepat sampai sepat), skoring aroma 3,45 (agak beraroma daun sampai beraroma daun), dan penerimaan keseluruhan 4,90 (agak suka).

\section{Saran}

Berdasarkan hasil penelitian yang telah dilakukan, disarankan menggunakan perlakuan blansir uap dengan suhu pengeringan $70^{\circ} \mathrm{C}$ untuk menghasilkan teh daun bambu tali dengan karakteristik terbaik, dan perlu dilakukan penelitian lebih lanjut mengenai variasi waktu tiap perlakuan dan lama penyeduhan teh.

\section{DAFTAR PUSTAKA}

Apriyantono, A., D. Fardiaz, D. Puspitasari, N.L. Yasni dan S. Budiyanto. 1989. Petunjuk Laboraturium Analisis Pangan. IPB Press, Bogor.

Asgar, A. dan D. Musaddad. 2006. Optimalisasi, cara, suhu dan lama blanching sebelum pengeringan kubis. J. Hort. 16(4):349-355.

Astatin, G.R. 2014. Pemanfaatan Daun Sirsak (Annona muricata Linn) dan Kulit Jeruk Purut (Cytrus hystrix) Sebagai Bahan Dasar Pembuatan Teh Dengan Variasi Lama Pengeringan. Skripsi S1. Tidak dipublikasikan. Fakultas Keguruan dan Ilmu Pendidikan. 
Universitas Muhammadiyah Surakarta, Surakarta.

Badan Standarisasi Nasional. 2013. SNI 3836-2013 Teh Kering dalam Kemasan. Badan Standarisasi Nasional, Jakarta.

Chu, D.J. dan L.R. Juneja, 1997. General Chemical Composition of Green Tea and Its Infusion in Chemistry and Application of Green Tea. CRC Press, New York.

Ciptadi, W. dan M.Z. Nasution. 1979. Mempelajari Cara Pemanfaatan Teh Hitam Mutu Rendah untuk Pembuatan Teh Dadak. IPB, Bogor.

Desrosier, N.W. 1988. Teknologi Pengawetan Pangan. Penerjemah Muljohardo. Universitas Indonesia, Jakarta.

Dransfield, S. dan E.A. Widjaja. 1995. Plant Resources of South-East Asia 7 Bambu. PROSEA Foundation, Bogor.

Dwivedi, V.N., N.P. Singh, S.S. Dash dan N.B. Singh. 2006. A new pozzolanic material for cement industry: bamboo leaf ash. International Journal of Physical Sciences. 1(3):106-111.

Gaman, P.M. dan K.B. Sherrington, 1992. Ilmu Pangan: Pengantar Ilmu Pangan Nutrisi dan Mikrobiologi. Gajah Mada Universitas Press, Yogyakarta.

Hadipernata, M., R. Rachmat dan Widaningrum. 2006. Pengaruh Suhu Pengeringan Pada Teknologi Far Infrared terhadap Mutu Jamur Merang Kering (Volvariella volvaceae). Buletin Teknologi Pasca Pertanian. Vol. 2.

Horzic, D., D. Komes, A. Belscak., K.K. Ganic., D. Ivekovic and D. Karlovic. 2009. The compositions of polyphenols and methylxantine in teas and herbal infusions. Food Chem. 115(2):441-448
Kusuma, I.G.N., I.N.K. Putra dan L.P.T Darmayanti. 2019. Pengaruh suhu pengeringan terhadap aktivitas antioksidan teh herbal kulit kakao (Theobroma cacao L.). Jurnal Ilmu dan Teknologi Pangan. 8(1):85-93.

Lidiasari, E., M.I. Syafutri dan F. Syaiful. 2006. Pengeruh perbedaan suhu pengeringan tepung tapai ubi kayu terhadap mutu fisik dan kimia yang dihasilkan. Jurnal Ilmu-Ilmu Pertanian Indonesia. 8(2):141-146.

Lund, D.B. 1975. Effect of Heat Processing on Nutrients. Chapter 9 in Nutrional Evaluation of Food Processing, Westport, Connecticut.

Molyneux, P. 2004. The use of the stable free radical diphenylpicrylhydrazyl (DPPH) for estimating antioxidant activity. Journal of Science Technology. 26(2):211-219.

Patin, E.W., M.A. Zaini dan Y. Sulastri. 2018. Pengaruh variasi suhu pengeringan terhadap sifat fisiko kimia teh daun sambiloto (Andrographis paniculata). Jurnal Ilmu dan Teknologi Pangan. 4(1):251-258.

Pratiwi, I.D.P.K. dan A.A.S. Wiadnyani. 2016. Kapasitas Antioksidan dan Flavonoid Bubuk Simplisia Daun Pegagan (Cantella asiatica (L) Urban). Proceedings of Seminar Nasional Sains dan Teknologi III, Denpasar-Bali: 1516 Desember 2016. Hal. 1-4.

Prayoga. G. 2013. Fraksinasi, uji aktivitas antioksidan dengan metode DPPH dan identifikasi golongan senyawa kimia dari ekstrak teraktif daun sambang darah (Excoecaria cochinchinensis Lour). Pharmacon. 5:41-48.

Ramlah, R. 2017. Penentuan Suhu dan Waktu Optimum Penyeduhan Daun Teh Hijau (Camellia sinensis L.) P+2 Terhadap 
Kandungan Antioksidan, Kafein, Tanin dan Katekin. Skripsi S1. Tidak dipublikasikan. Fakultas Sains dan Teknologi. UIN Alauddin, Makassar.

Rusnayanti, Y. 2018. Pengaruh Suhu dan Lama Pengeringan Terhadap Mutu Teh Hijau Daun Kakao (Theobroma cacao L.). Skripsi S1. Tidak dipublikasikan. Fakultas Teknologi Pangan dan Agroindustri. Universitas Mataram, Mataram.

Sakanaka, S., Y. Tachibana, Okad and Yuki. 2005. Preparation and antioxidant properties of extract of Japanese persimmon leaf (Kakinocha-cha). Food Chemistry. 89(4):569-575.

Setiawan, A.A., L.Y. Aditama dan Yusransyah. 2018. Uji aktivitas anti jamur ekstrak daun bambu tali (Gigantochloa apus) terhadap jamur Candida albicans. Farmagazine. 5(2):12-22.

Soekarto, S.T. 1985. Penilaian Organoleptik (untuk Industri Pangan dan Hasil Pertanian). Penerbit Bharata Karya Aksara, Yogyakarta.
Sudarmadji, S., B. Haryono dan Suhardi. 1997. Prosedur Analisa untuk Bahan Makanan dan Pertanian. Liberty, Yogyakarta.

Tongco, J.V.V., R.M. Aguda and R.A. Razal. 2014. Proximate analysis, phytochemical screening, and total phenolic and flavonoid content of Philippine bamboo Schizotachyum lumampao. Journal of Chemical and Pharmacheutical Research. 6(1):709713.

Winarno, F.G. 2008. Kimia Pangan dan Gizi. PT. Gramedia, Jakarta.

Yuliani, N.N. dan D.P. Dienina. 2015. Uji aktivitas antioksidan infusa daun kelor (Moringa oleifera Lamk) dengan metode 1,1-diphenyl-2-picrylhydrazyl (DPPH). Jurnal Info Kesehatan. 14(2):1061-1082. 